\title{
Assessing the long-term geomorphic stability of a rehabilitated landform using the CAESAR-Lisflood landscape evolution model
}

J.B.C. Lowry Department of Sustainability, Environment, Water, Populations and Communities, Australia

T.J. Coulthard Department of Geography, University of Hull, UK

G.R. Hancock Department of Geology, University of Newcastle, Australia

\begin{abstract}
The ability to accurately predict the stability of post-mining landscapes through time scales ranging from decades to thousands of years is a critical element in the assessment of closure designs for uranium mines. In this paper, the CAESAR-Lisflood Landscape Evolution Model (LEM) is used to simulate and assess the geomorphic stability of a conceptual rehabilitated landform of the Ranger Uranium Mine in the Northern Territory, Australia. Crucially, this is the first time that the CAESAR-Lisflood model has been applied to an entire conceptual rehabilitated mine landform.
\end{abstract}

Following construction of the landform and subject to environmental conditions, erosion features such as gullies may erode containment structures, potentially leading to the exposure and transport of encapsulated radioactive material. Further, erosion may lead to increased sediment loads and the transport of other mine-related contaminants off site and into downstream waterways. LEMs can provide information on soil erosion rates at annual to millennial time scales, over large spatial scales, and can also evaluate the sensitivity of these processes to environmental changes.

The CAESAR-Lisflood LEM requires several data inputs to run simulations to assess these processes. Particle size distribution and rainfall data were obtained from field measurements on the Ranger lease, and the Bureau of Meteorology. A digital elevation model (DEM) of the conceptual rehabilitated landform of the mine, which was used to simulate changes to the landform surface under a variety of model scenarios, was generated through the integration of landform design plans supplied by mine operator, Energy Resources of Australia (ERA), with a high resolution LiDAR DEM of the surrounding undisturbed environment.

For the purposes of this study, the CAESAR-Lisflood model was modified to enable the differential consolidation of areas representing capped pits on the landform to be modelled. Model scenarios run by CAESAR-Lisflood included the effect of vegetated/unvegetated and consolidated/ unconsolidated surfaces over simulated time periods of 45 and 1,000 years. The 45-year scenarios were used to assess the stability of the landform in the period after the initial construction of the landform once all consolidation had occurred. The 1,000-year scenarios were used to assess the longer-term stability of the landform. Several simulated scenarios identified the potential for large-scale erosion to occur on the landform, potentially exposing buried contaminants. Initial model results provide a guide to areas of improvement in both landform design and the enhancement of the modelling software. The results from simulations of the conceptual landform provide increased confidence that the CAESAR-Lisflood LEM will be able to correctly predict the evolution of a rehabilitated landform once it has been constructed.

\section{Introduction}

The Ranger Uranium Mine operated by Energy Resources of Australia Ltd (ERA) currently accounts for about $10 \%$ of the world's annual production of uranium oxide. It is located in the catchment of Magela Creek in the wet-dry tropics of the Northern Territory of Australia (Figure 1). Mining of the open cut ore 
body ceased in 2012, and milling and production are scheduled to cease by 2020 . The unique location of the mine site - surrounded by the World Heritage Listed Kakadu National Park and upstream of floodplains and wetlands listed as Wetlands of International Significance under the Ramsar Convention - has meant that the development of closure criteria and rehabilitation plans for the mine has required special consideration.

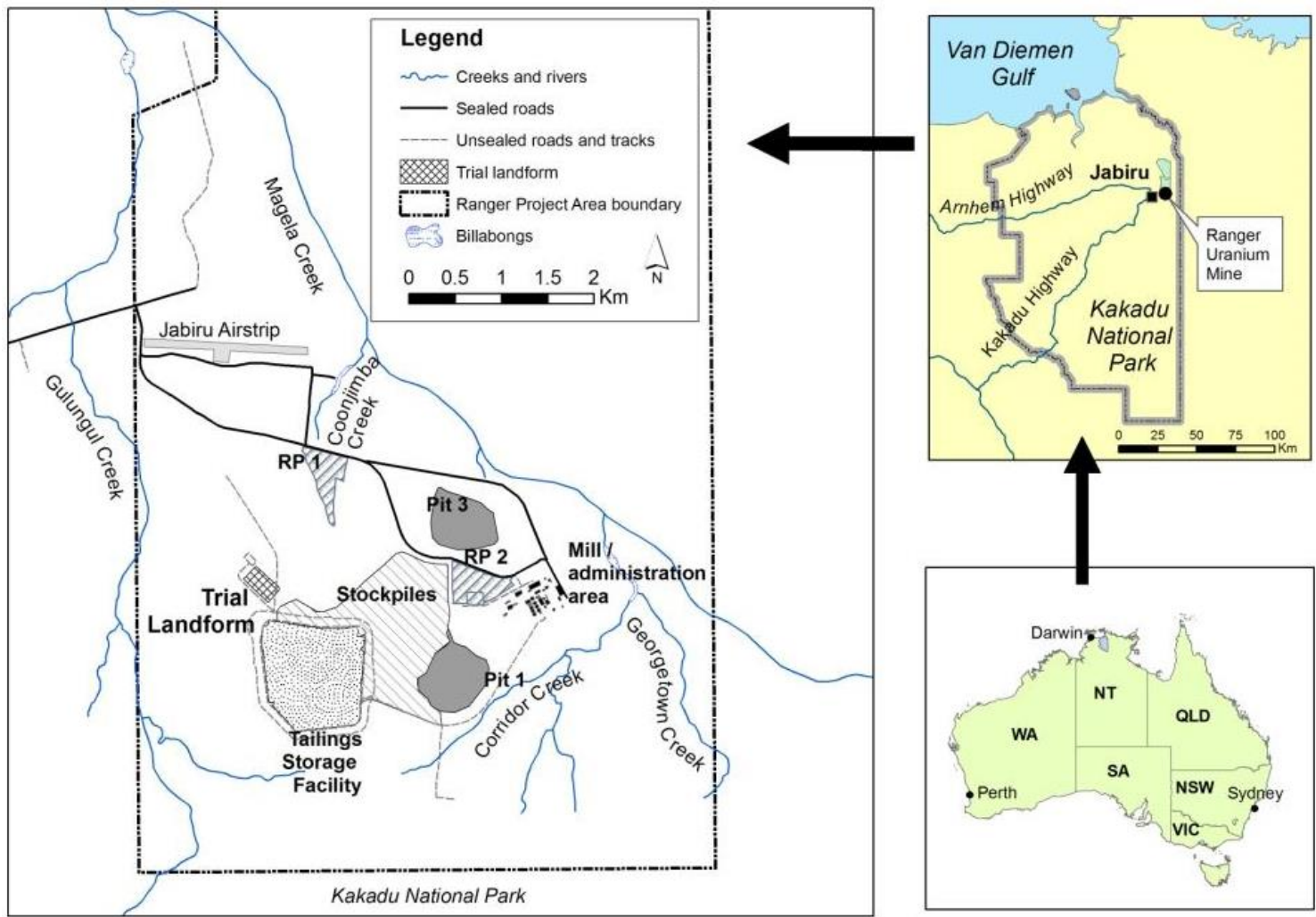

\section{Figure 1 Location of the Ranger Mine}

Reflecting the environmental and cultural sensitivities of the area, the Supervising Scientist Division of the Commonwealth Department of Sustainability, Environment, Water, Population and Communities undertakes an independent physical, chemical and biological monitoring programme in the river catchments around the mine to ensure that the environment outside of the mine project area remains protected (Jones et al., 2009).

Given the environmental and cultural sensitivity of the area surrounding the mine, it is important to determine the likely erosional stability of the proposed rehabilitated landform through time, to ensure that post closure environmental protection objectives are met. The environmental requirements for mine closure specify that the final landform should possess

"erosion characteristics which, as far as can reasonably be achieved, do not vary significantly from those of comparable landforms in surrounding undisturbed areas" (Supervising Scientist Division, 1999).

It is therefore crucial that rehabilitation planning and landform design incorporate landform shape and surface treatments that reduce erosion and minimise release of contaminants. Specifically, erosion should not result in gullying, which may expose contained waste material to the environment within a specified time period.

Landform evolution modelling provides a means for assessing the potential performance of constructed mine landforms. Over the last 40 years a variety of models have been used to evaluate erosion and simulate post-mining landscape stability (Evans, 2000; Loch et al., 2000). These models include the water erosion prediction programme (Laflen et al., 1991), the universal soil loss equation, the modified universal 
soil loss equation, the revised universal soil loss equation (Onstad and Foster, 1975; Wischmeier and Smith, 1978; Renard et al., 1994) and Siberia (Willgoose et al., 1989).

The CAESAR model (Coulthard et al., 2000, 2002) was originally developed to examine the effects of environmental change on river evolution and to study the movement of contaminated river sediments. Recently, it has been modified and applied to study the evolution of proposed rehabilitated mine landforms in northern Australia (Hancock et al., 2010; Lowry et al., 2011; Saynor et al., 2012). In this paper, CAESARLisflood, an enhanced version of the CAESAR Landscape Evolution Model (LEM), is used to simulate and assess the geomorphic stability of a conceptual rehabilitated landform of the Ranger Uranium Mine in the Northern Territory, Australia.

\section{CAESAR-Lisflood model}

CAESAR-Lisflood is the latest iteration of the CAESAR model. It combines the Lisflood-FP $2 \mathrm{~d}$ hydrodynamic flow model (Bates et al., 2010) with the CAESAR geomorphic model (Coulthard et al., 2000, 2002, 2005; Van De Wiel et al., 2007)) to simulate erosion and deposition in river catchments and reaches over time scales from hours to thousands of years. The model does this by routing water over a regular grid of cells and altering elevations according to erosion and deposition from fluvial and slope processes. CAESAR-Lisflood can be run in two modes: a catchment mode (as used here), with no external in-fluxes other than rainfall, and a reach mode, with one or more points where sediment and water enter the system. For both modes the model requires the specification of several parameters or initial conditions, including elevation, grain sizes and rainfall (catchment mode), or a flow input (reach mode). The initial topography of the landscape drives fluvial and hillslope processes that determine the spatial distribution of erosion (loss) and deposition (gain) that occurs during a given time step. This altered topography becomes the starting point for the next time step. Outputs of the model are elevation and sediment distributions through space and time and discharges and sediment fluxes at the outlet(s) through time. There are four main components to CAESARLisflood: a hydrological model, a flow model, fluvial erosion and deposition and slope processes.

When running in catchment mode, runoff over the catchment is generated through the input of rainfall data. The surface runoff generated by the hydrological model is then routed using a flow model.

Although flow is the main driver of the model, morphological changes result from entrainment, transport and deposition of sediments. CAESAR-Lisflood can accept up to nine size-based fractions of sediment that are transported either as bed load or as suspended load, depending on the grain sizes. CAESAR-Lisflood provides two different methods of calculating sediment transport, based on the Einstein (1950) and the Wilcock and Crowe (2003) equations. For this application, the Einstein method was used.

A key attribute of the CAESAR-Lisflood model is the ability to utilise hourly recorded rainfall data from the study area, enabling the modelling of the effects of specific rainfall events. Event modelling is critical, especially for the early stages of landform evolution, since it is recognised that the majority of erosion typically occurs during a limited number of high-intensity events (Moliere et al., 2002). As the climatic region in which the Ranger Mine occurs is dominated by seasonal, high-intensity rainfall events (McQuade et al., 1996), the ability to model specific rainfall events meant that the CAESAR-Lisflood model was the model of choice for this project.

\section{$3 \quad$ Methodology}

The application of the CAESAR model to the trial landform required the collation and integration of data from a range of different sources. The key data inputs used by the model were a digital elevation model (DEM), rainfall data and surface particle size data.

\subsection{Digital Elevation Models}

DEMs representing surcharged and non-surcharged versions of the conceptual landform were supplied by ERA (Figure 2). The former incorporated an additional quantity of material that rises an additional $12 \mathrm{~m}$ 
above the surrounding landform, over the footprint of Pit 1 . The surcharge is designed to accommodate the extent of vertical consolidation predicted to occur through time in the covered mass of tailings in the pit. The non-surcharged landform represents the end member post-consolidation landform, in which no further consolidation of the landform is anticipated.

The DEMs were generated through the integration of $2 \mathrm{~m}$ interval contour data produced from a LiDAR survey of the mine in 2011, with $2 \mathrm{~m}$ contours representing the various conceptual landform scenarios to produce a grid surface with a horizontal resolution of $2 \mathrm{~m}$. The final DEMs used for modelling purposes were compiled to a horizontal spatial resolution of $10 \mathrm{~m}$, which was determined to be the optimal resolution at which the CAESAR-LisFlood model could function within the spatial extent of the study catchments and over the temporal periods modelled.
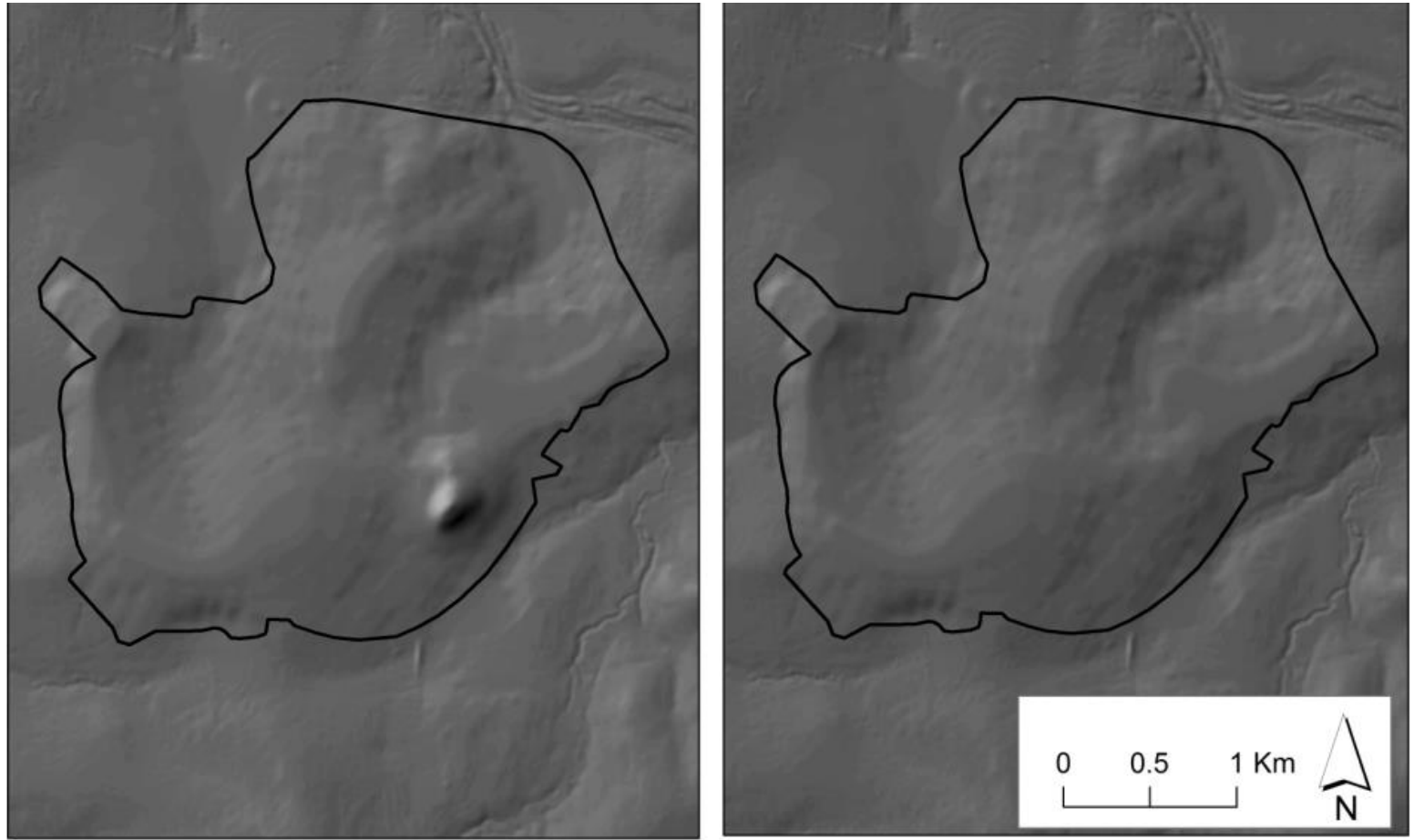

\section{Figure 2 Surcharged (left) and non-surcharged DEMs of the landform; the black line represents the boundary of the rehabilitated landform}

For the purposes of this study, the DEMs of the different conceptual landforms (surcharged, nonsurcharged) were divided into a series of subcatchments that were individually modelled (Figure 3 ).

\subsection{Rainfall}

Twenty-two years of complete (i.e., no gaps in the annual dataset) hourly rainfall intensity data are available for the period between 1971 and 2006 for Jabiru airport, $2 \mathrm{~km}$ northwest of the Ranger mine site. The one-hour rainfall totals $(\mathrm{mm})$ for the 22 years were used to form the rainfall inputs for the different scenarios modelled using CAESAR-Lisflood.

Rainfall data were compiled for two scenarios:

- A 45-year simulation, in which the 22 years of rainfall data over the period 1971-2006 were looped to run twice for a simulated period of 44 years, with the addition of the extreme rainfall event from March 2007 at the end of the second loop. In the course of the latter event, $785 \mathrm{~mm}$ of rainfall were recorded in the three-day period between 27 February and 2 March; rainfall intensity in this period exceeded a 1-in-100 year storm event.

- A 1,000 year simulation was run in which the 22-year Jabiru rainfall was looped out to a period of 1,000 years. The 2007 extreme rainfall event was not used in this simulation. 


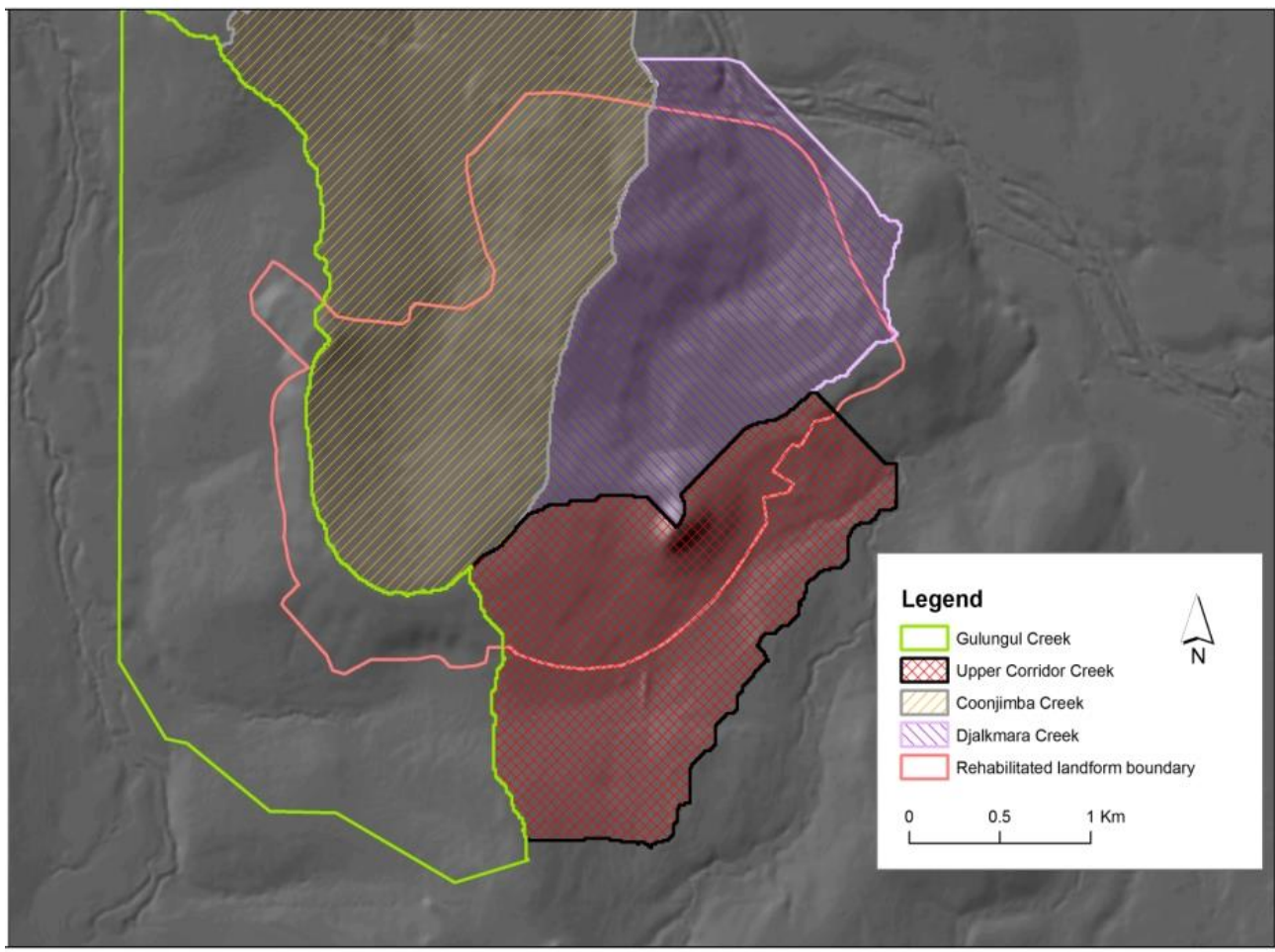

\section{Figure 3 Catchment areas used for assessing the Ranger conceptual landform}

\subsection{Grain size data}

For the purposes of this study, grain size data were obtained from waste rock material collected on an 8 hectare trial rehabilitated landform at Ranger in the 2009 dry season.

Using the process described in Saynor and Houghton (2011), the grain size data for CAESAR-Lisflood were obtained from size-fractionated bulk samples of surface material collected at eight points on the waste rock surface of the trial landform. Grain size analysis was completed on these samples and the results averaged into nine grain size classes (Figure 4) which were used for input into CAESAR-Lisflood. The sub $0.00063 \mathrm{~m}$ (i.e., $63 \mu \mathrm{m}$ ) fraction is treated as suspended sediment within CAESAR-Lisflood.

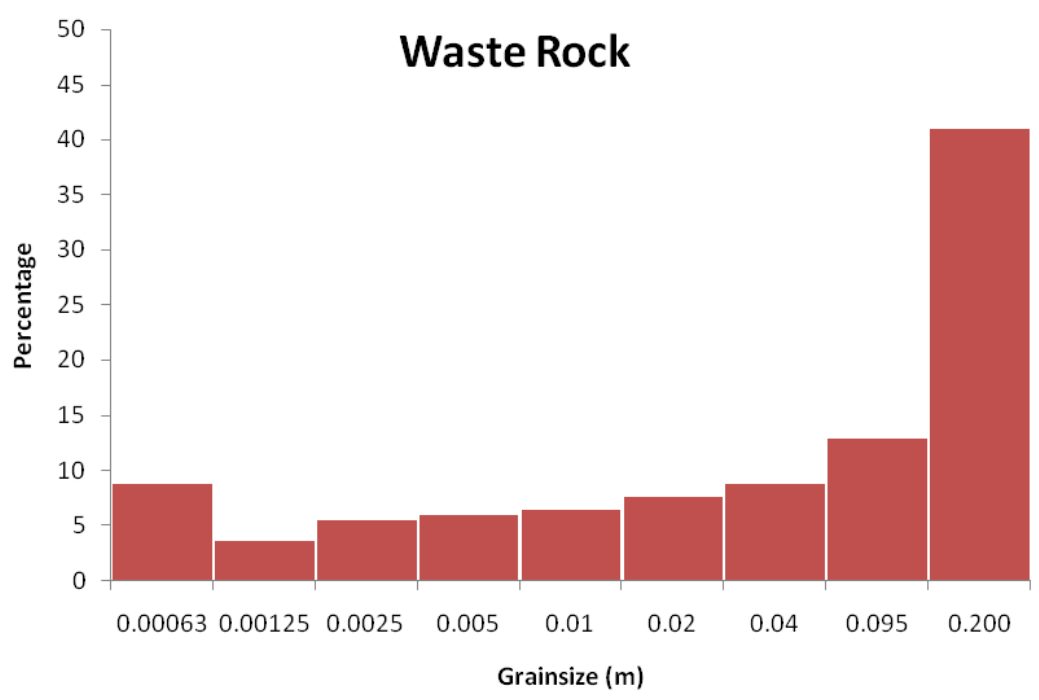

Figure 4 Grain size distribution of waste rock used in simulations 
Importantly, the model assumed that the entire surface of the landform was composed of waste rock material.

\subsection{Differential consolidation}

The effect of differential consolidation on the surface of the surcharged landform was done by calculating the depth of tailings fill placed in Pit 1 . The depth of tailings was calculated by subtracting the present-day LiDAR DEM of Pit 1 (filled with tailings) from a DEM of the unfilled pit 1 and creating a file of tailings depths. ATC-Williams (2009) simulated consolidation over five core depths $(30,60,90,120$ and $150 \mathrm{~m})$ and provided a point data file for each of these depths. Exponential decay functions were fitted to the consolidation time series data. These functions were then built into the model so that consolidation occurred at the correct rates and extents across the backfilled pit area of the model domain. CAESARLisflood determined the consolidation rates for fill depths between these values by interpolating between the rates for different depths.

\subsection{Model scenarios}

Simulations were done on a catchment-by-catchment basis, for vegetated 'best case' and unvegetated 'worst case' scenarios of simulated periods of 45 years and 1,000 years. Vegetated scenarios simulated the development of a mature grass community on the landform. In the case of the Corridor and Djalkmara Creek catchments, additional simulations were done to investigate the impact of the consolidation of the landform. The 45-year time frame was used to model the evolution of the landform within the time frame in which consolidation was likely to occur on the landform, whilst the 1,000-year time frame was used to provide a longer-term analysis of the landform evolution.

\section{$4 \quad$ Results and discussion}

The sediment yield produced by the different scenarios modelled in the Corridor Creek catchment show that for equivalent surface conditions, there is little difference between the surcharged and nonsurcharged landforms for periods of 45 years (Table 1 ) and 1,000 years (Table 2). Similarly, there is little difference in the sediment yields produced by the same surface conditions of the surcharged and nonsurcharged landforms in Djalkmara Creek catchment at 45 years (Table 3) and 1,000 years (Table 4).

In Djalkmara catchment, a vegetated non-surcharged landform is predicted to produce a slightly lower long-term denudation rate than a vegetated consolidated surcharged landform. However, in practice some degree of initial surcharge will be needed for construction of the landform over Pit 1 to ensure that the final landform elevation is achieved, accounting for the ultimate consolidation of the underlying tailings mass.

Table 1 Sediment yields and denudation rates after 45 years from CAESAR-Lisflood Corridor Creek (304 ha)

\begin{tabular}{|c|c|c|c|c|c|c|}
\hline & \multicolumn{4}{|c|}{ Surcharged } & \multicolumn{2}{|c|}{ No Surcharge } \\
\hline & \multicolumn{2}{|c|}{ Vegetated } & \multicolumn{2}{|c|}{ No Vegetation } & \multirow[t]{2}{*}{ Vegetated } & \multirow[t]{2}{*}{ No Vegetation } \\
\hline & Consolidation & $\begin{array}{c}\text { No Consolidation } \\
\text { (static) }\end{array}$ & Consolidation & $\begin{array}{c}\text { No Consolidation } \\
\text { (static) }\end{array}$ & & \\
\hline Total load $\left(\mathrm{m}^{3}\right)$ & 45295 & 53737 & 80354 & 127320 & 49035 & 130144 \\
\hline $\begin{array}{l}\text { Denudation } \\
\text { rate (mm y-1) }\end{array}$ & 0.33 & 0.39 & 0.59 & 0.93 & 0.36 & 0.95 \\
\hline
\end{tabular}


Table 2 Sediment yields and denudation rates after 1,000 years from CAESARLisflood - Corridor Creek (304 ha)

\begin{tabular}{|c|c|c|c|c|c|c|}
\hline & \multicolumn{4}{|c|}{ Surcharged } & \multicolumn{2}{|c|}{ No Surcharge } \\
\hline & \multicolumn{2}{|c|}{ Vegetated } & \multicolumn{2}{|c|}{ No Vegetation } & \multirow[t]{2}{*}{ Vegetated } & \multirow[t]{2}{*}{ No Vegetation } \\
\hline & Consolidation & $\begin{array}{c}\text { No Consolidation } \\
\text { (static) }\end{array}$ & Consolidation & $\begin{array}{c}\text { No Consolidation } \\
\text { (static) }\end{array}$ & & \\
\hline Total Load $\left(\mathrm{m}^{3}\right)$ & 262175 & 290704 & 610819 & 646966 & 258498 & 615593 \\
\hline $\begin{array}{l}\text { Denudation } \\
\text { rate }\left(\mathrm{mm} \mathrm{y}^{-1}\right)\end{array}$ & 0.09 & 0.1 & 0.2 & 0.21 & 0.09 & 0.20 \\
\hline
\end{tabular}

Table 3 Sediment yield and denudation rates after 45 years from CAESAR-Lisflood Djalkmara catchment (293 ha)

\begin{tabular}{|c|c|c|c|c|c|c|}
\hline & \multicolumn{4}{|c|}{ Surcharge } & \multicolumn{2}{|c|}{ No Surcharge } \\
\hline & \multicolumn{2}{|c|}{ Vegetated } & \multicolumn{2}{|c|}{ No Vegetation } & \multirow[t]{2}{*}{ Vegetated } & \multirow{2}{*}{$\begin{array}{c}\text { No } \\
\text { Vegetation }\end{array}$} \\
\hline & Consolidation & $\begin{array}{c}\text { No Consolidation } \\
\text { (static) }\end{array}$ & Consolidation & $\begin{array}{c}\text { No } \\
\text { Consolidation } \\
\text { (static) }\end{array}$ & & \\
\hline Total Load $\left(\mathrm{m}^{3}\right)$ & 37600 & 39172 & 240323 & 219512 & 39385 & 170821 \\
\hline $\begin{array}{l}\text { Denudation rate } \\
\qquad\left(\mathrm{mm} \mathrm{y}^{-1}\right)\end{array}$ & 0.29 & 0.30 & 1.82 & 1.66 & 0.30 & 1.30 \\
\hline
\end{tabular}

Table 4 Sediment yield and denudation rates after 1,000 years from CAESAR-Lisflood - Djalkmara catchment (293 ha)

\begin{tabular}{|c|c|c|c|c|c|c|}
\hline & \multicolumn{4}{|c|}{ Surcharge } & \multicolumn{2}{|c|}{ No Surcharge } \\
\hline & \multicolumn{2}{|c|}{ Vegetated } & \multicolumn{2}{|c|}{ No Vegetation } & \multirow[t]{2}{*}{ Vegetated } & \multirow[t]{2}{*}{ No Vegetation } \\
\hline & Consolidation & $\begin{array}{c}\text { No Consolidation } \\
\text { (static) }\end{array}$ & Consolidation & $\begin{array}{c}\text { No Consolidation } \\
\text { (static) }\end{array}$ & & \\
\hline Total Load $\left(\mathrm{m}^{3}\right)$ & 582365 & 572237 & 3381335 & 3338057 & 546430 & 3522639 \\
\hline $\begin{array}{l}\text { Denudation rate } \\
\qquad\left(\mathrm{mm} \mathrm{y}^{-1}\right)\end{array}$ & 0.20 & 0.20 & 1.15 & 1.14 & 0.19 & 1.20 \\
\hline
\end{tabular}

Short-term (Table 5) and long-term (Table 6) simulations of both Coonjimba and Gulungul Creeks reinforce the role of vegetation in reducing erosion. However, Coonjimba Creek would appear to produce the highest sediment yield of all catchments studied, under both vegetated and unvegetated scenarios $\left(174,479 \mathrm{~m}^{3}\right.$ and $513,058 \mathrm{~m}^{3}$ respectively). This compares with predicted sediment yields in Gulungul Creek $\left(41,537 \mathrm{~m}^{3}\right.$ vegetated and $100,894 \mathrm{~m}^{3}$ unvegetated) and Djalkmara $\left(37,600 \mathrm{~m}^{3}\right.$ vegetated and $215,818 \mathrm{~m}^{3}$ unvegetated). 


\section{Table 5 Sediment yield and denudation rates after 45 years from CAESAR-Lisflood for the Coonjimba and Gulungul catchments}

\begin{tabular}{lcccc}
\hline Catchment & Area (ha) & & Vegetated & No Vegetation \\
\hline Coonjimba & 493 & Total Load $\left(\mathrm{m}^{3}\right)$ & 174479 & 513058 \\
& & Denudation rate $\left(\mathrm{mm} \mathrm{y}^{-1}\right)$ & 0.79 & 2.31 \\
Gulungul & 554 & Total Load $\left(\mathrm{m}^{3}\right)$ & 41537 & 100894 \\
& & Denudation rate $\left(\mathrm{mm} \mathrm{y}^{-1}\right)$ & 0.17 & 0.40 \\
\hline
\end{tabular}

Table 6 Sediment yield and denudation rates after 1,000 years from CAESAR-Lisflood for the Coonjimba and Gulungul catchments

\begin{tabular}{|c|c|c|c|c|}
\hline Catchment & Area (ha) & & Vegetated & No Vegetation \\
\hline \multirow[t]{2}{*}{ Coonjimba } & 493 & Total Load $\left(\mathrm{m}^{3}\right)$ & 1834572 & 7579650 \\
\hline & & Denudation rate $\left(\mathrm{mm} \mathrm{y}^{-1}\right)$ & 0.37 & 1.53 \\
\hline \multirow[t]{2}{*}{ Gulungul } & 554 & Total Load $\left(\mathrm{m}^{3}\right)$ & 341428 & 1181649 \\
\hline & & Denudation rate $\left(\mathrm{mm} \mathrm{y}^{-1}\right)$ & 0.06 & 0.21 \\
\hline
\end{tabular}

The 'worst case' scenario of an unvegetated surcharged landform in Corridor Creek predicted the formation of a $2.5 \mathrm{~m}$ deep and $300 \mathrm{~m}$ wide gully on the side of the landform currently occupied by Pit 1 over a period of 1,000 years (Figure 5). The 'best case' scenario of a vegetated surcharged landform predicted incipient gully formation in the same region as the 'worst case' scenario within the same initial simulation period of 45 years. Long-term simulations to 1,000 years indicate that this gully could reach a depth of $4 \mathrm{~m}$ (Figure 6), and that the channel of Corridor Creek would continue to deepen, with several additional gullies forming on the sides of the landform that feed into Corridor Creek. However, the presence of vegetation appears to minimise the lateral expansion of the gullies.

Djalkmara Creek will re-establish itself in Djalkmara catchment, rising at the base of Pit 1 and flowing north through the area currently occupied by Pit 3 within a period of 45 years. Gullies of up to $12 \mathrm{~m}$ deep are predicted to occur in the catchment of Djalkmara creek under vegetated conditions over a period of 1,000 years. Of particular concern is the predicted formation of a $7 \mathrm{~m}$ deep by $300 \mathrm{~m}$ wide channel belt / incised floodplain in the area currently occupied by Pit 3 in the catchment over a period of 1,000 years under unvegetated 'worst case' conditions (Figure 7).

As with the simulations in Corridor Creek, an important difference between the vegetated 'best case' and unvegetated 'worst case' outputs was the formation of narrow, incised channels in those scenarios with vegetation, versus broader, initially shallower channels produced by the unvegetated scenarios. 

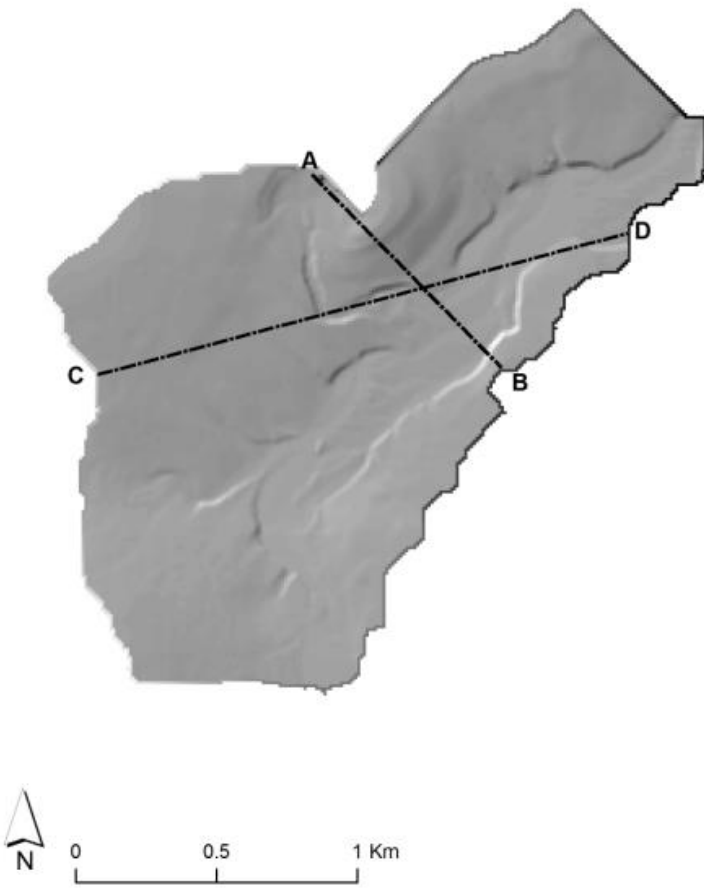
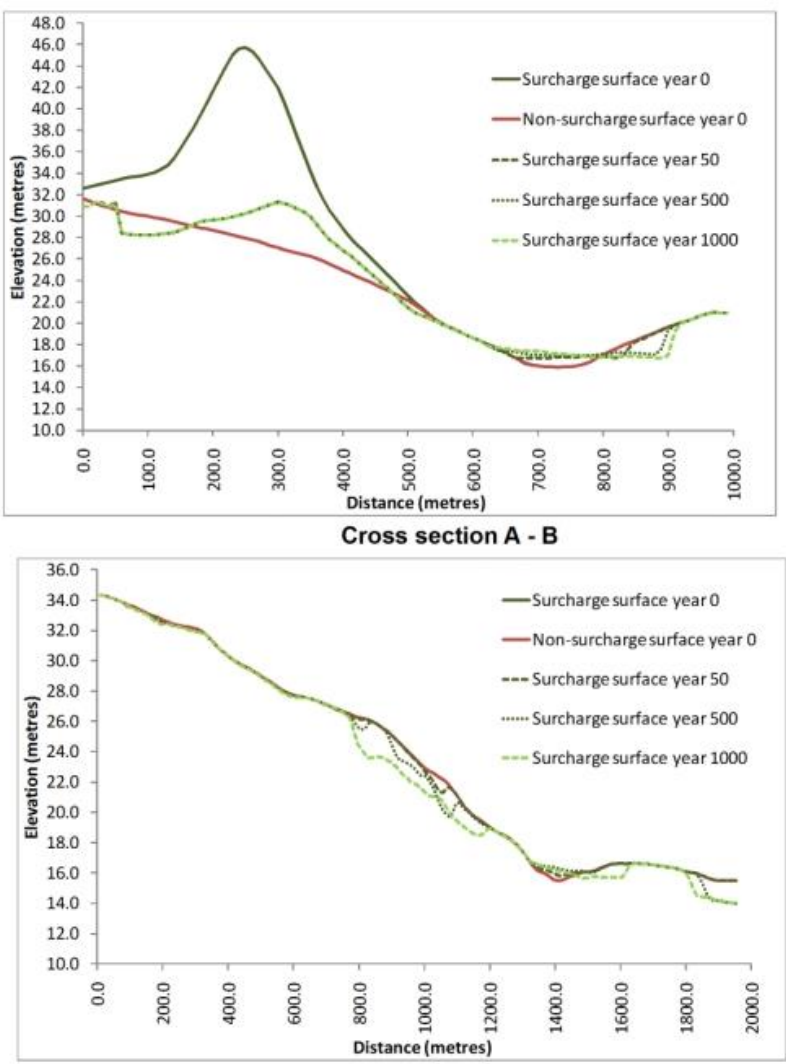

Cross section C - D

Figure 5 Unvegetated 'worst case' 1,000-year surface of upper Corridor Creek catchment 

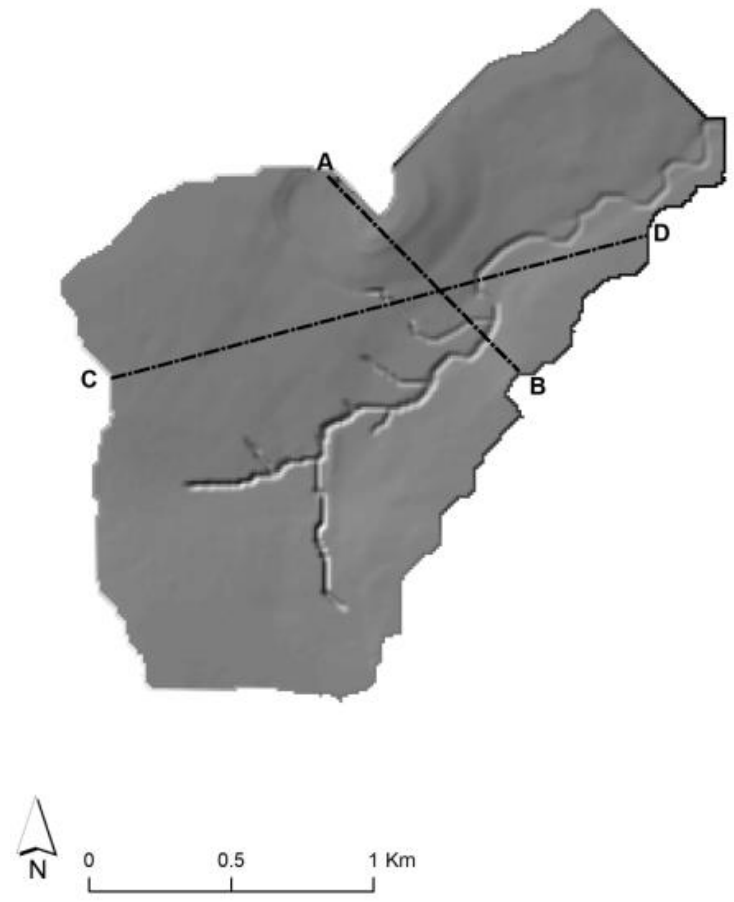

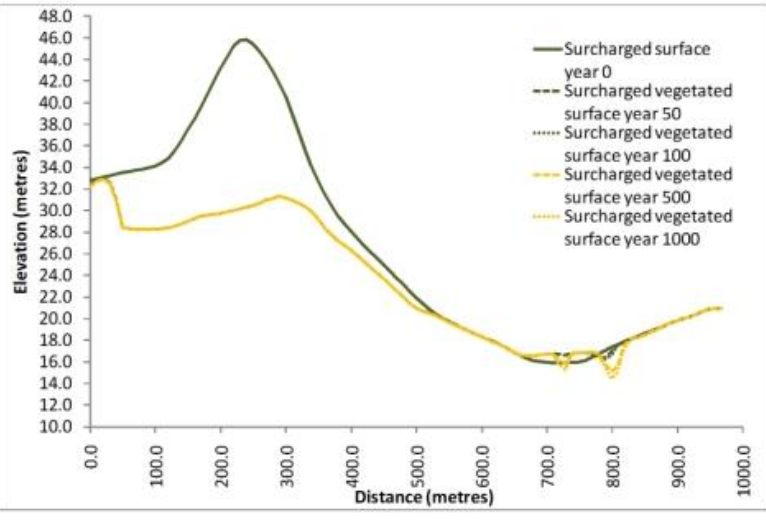

Cross section A - B

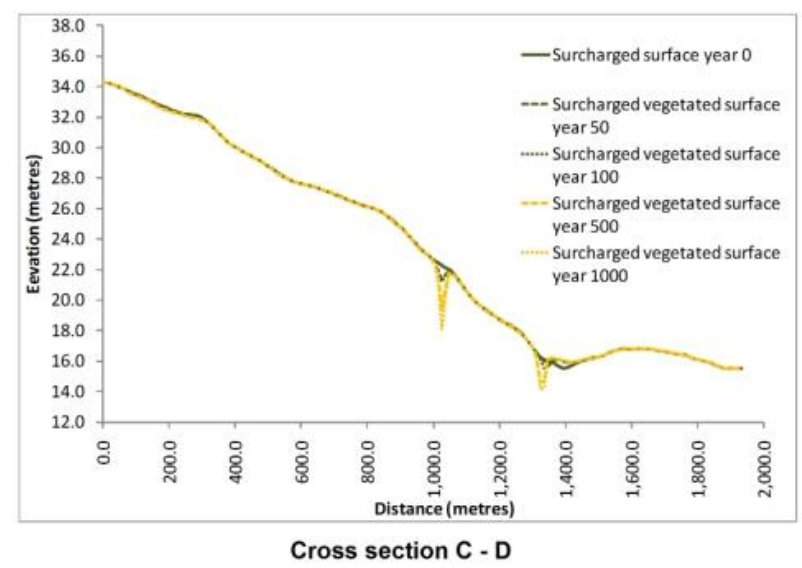

Figure 6 Vegetated 'best case' 1,000-year surface of upper Corridor Creek catchment 

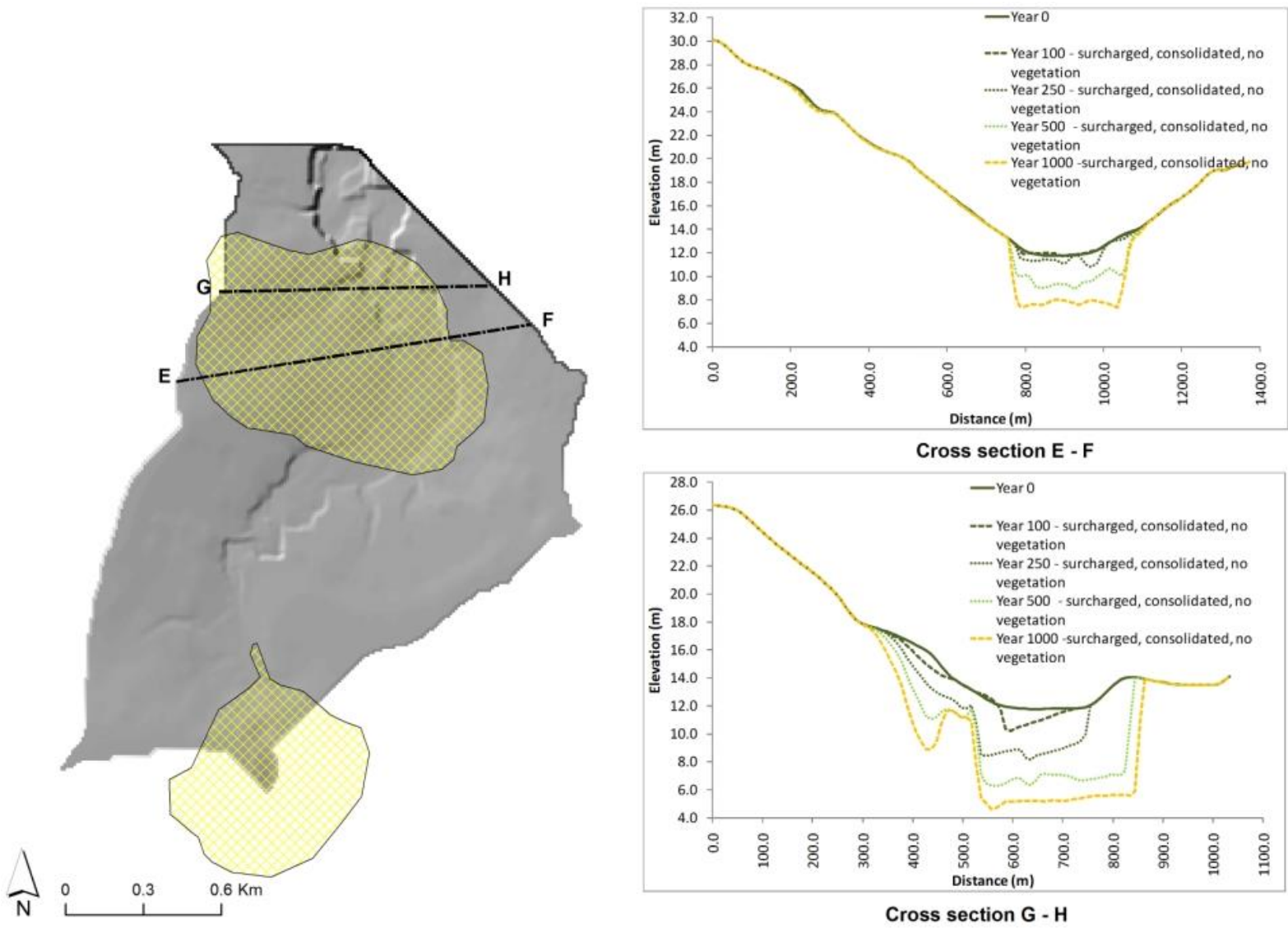

Figure 7 Unvegetated 'worst case' 1,000-year surface of Djalkmara Creek catchment; hatched areas represent current extent of Pit 1 (lower) and Pit 3 (upper)

The relative proportions of the total sediment yield in Djalkmara catchment were representative of the sediment load in all the catchments modelled, with the majority composed of bedload, with a small proportion (10-20\%) of suspended material (Figure 8). Importantly, the impact of an extreme weather event can also be seen in Figure 8, where the rainfall data for the extreme rain event recorded in March 2007 is introduced at the end of the 45-year cycle and can be seen to produce increased sediment loads off the (unvegetated) landform.

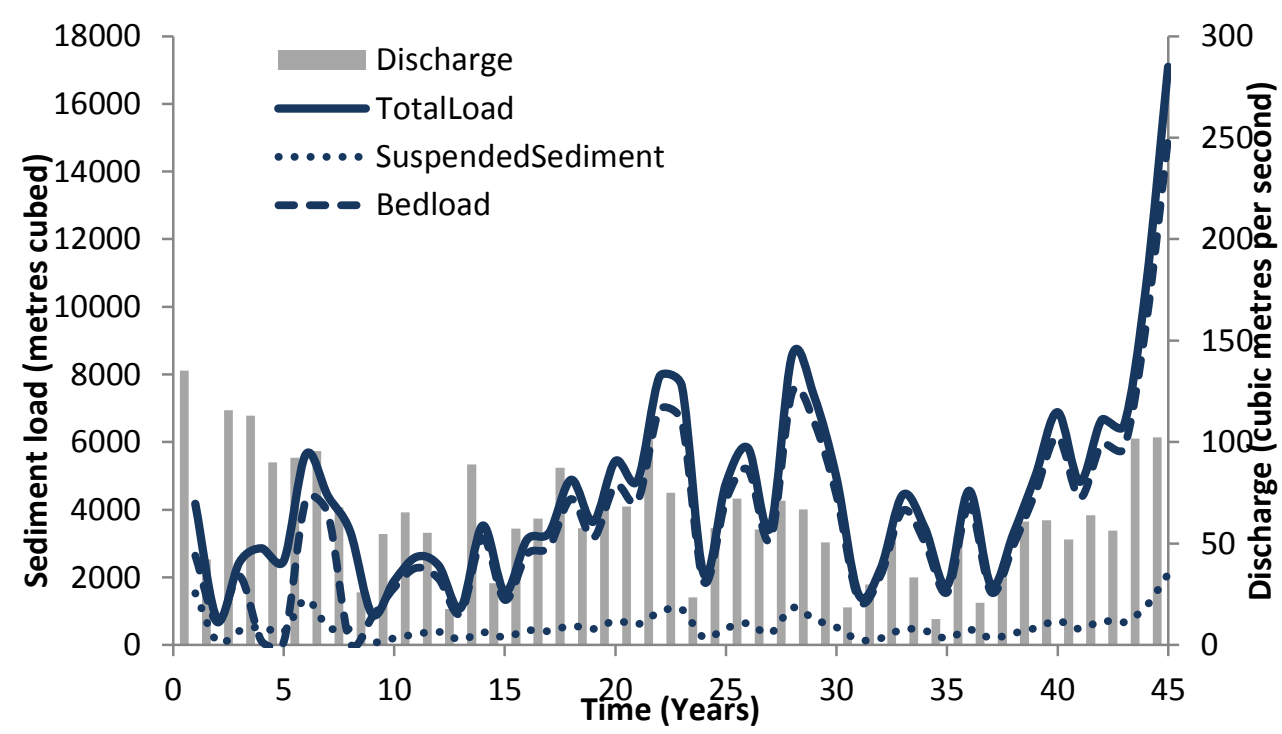

Figure 8 Variation in bedload and suspended load in unvegetated Djalkmara catchment over 45 -year period 
Coonjimba Creek will re-establish itself in Coonjimba catchment, rising in the area currently occupied by the Tailings Retention Facility and flowing north through the area currently occupied by RP1. Gullies up to $12 \mathrm{~m}$ deep are predicted to form in both the upper and lower reaches of the catchment under vegetated conditions, whilst a channel belt $300 \mathrm{~m}$ wide by $11 \mathrm{~m}$ deep is predicted to form in the lower reaches of the catchment (including the area currently occupied by RP1) under unvegetated conditions over 1,000 years (Figure 9).
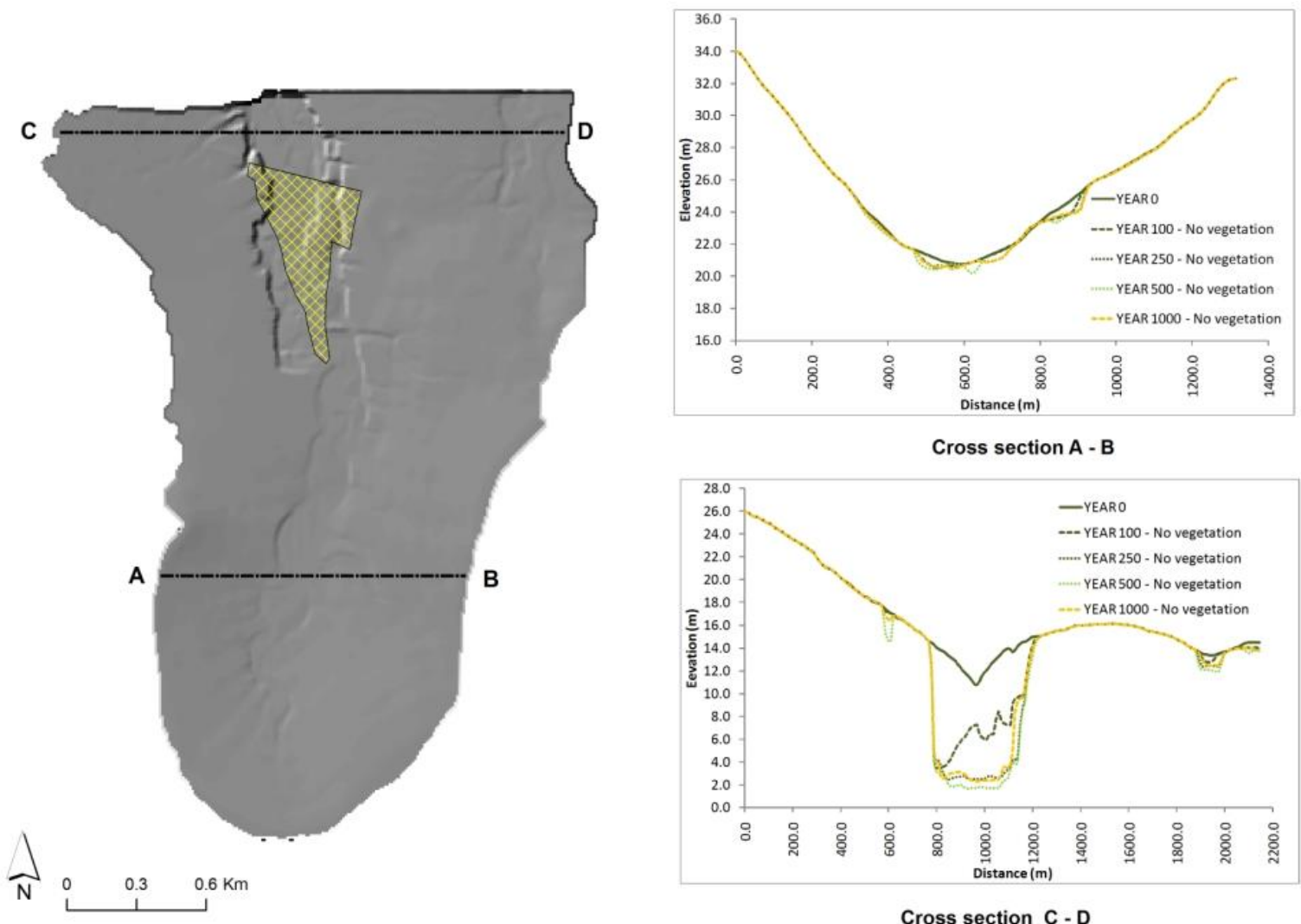

\section{Figure 9 Unvegetated 'worst case' 1,000-year surface of Coonjimba Creek catchment; hatched area represents current location of RP1}

Within a 45-year period, Gulungul Creek is likely to experience net infilling of existing drainage lines under both vegetated and unvegetated scenarios. Within a simulated period of 1,000 years, under an unvegetated scenario material from the upper regions of the catchment will be transported via geomorphic processes to the lower regions of the catchment, contributing to lateral migration and movement of the channels in the region. A vegetated scenario over the same time period predicts further incision of drainage features in the upper catchment to depths of up to $5 \mathrm{~m}$, whilst erosion/ incision of up to $1 \mathrm{~m}$ will occur in the lower region of the catchment.

Denudation is the process of washing away of surface materials. The denudation rates for each scenario shown in Tables 1 and 2 reflect the predictions of the total loads produced for each scenario. Predicted denudation rates are higher than published rates $\left(0.01-0.04 \mathrm{~mm} \mathrm{y}^{-1}\right)$ of natural denudation for the region, determined using stream sediment data from a range of catchments of different sizes (Cull et al., 1992; Erskine and Saynor, 2000).

The higher rates predicted by the simulations are likely due to the very high 'first flush' of sediment produced as the newly constructed surface undergoes equilibration. That is, finer particles on the fresh surface are preferentially eroded, and irregularities in the model DEM surface are removed, resulting in initially higher sediment yields. This is an important strength of the model and provides a representation of what the erosion behaviour is likely to be when the landform is first constructed. This is borne out by the good agreement between field-measured and CAESAR-predicted erosion rates for the Ranger trial landform 
(Lowry et al., 2011; Saynor et al., 2012). When the simulations were extended to a period of 1,000 years, the denudation rates were greatly reduced. This is not surprising, as the lower rates are an artefact of the length of period for which the data were averaged.

\section{$5 \quad$ Conclusions}

The results of the simulations described in this study have identified a number of issues that are likely to have an impact on the stability and/or integrity of the conceptual rehabilitated landform. A specific concern is the prediction of large-scale erosion producing channels hundreds of metres wide and/or tens of metres deep in the catchments of Corridor, Djalkmara and Coonjimba creeks over a period of 1,000 years, regardless of whether vegetation is present. While the magnitude of the predicted gully formation may be considered indicative of likely erosion patterns, the consistent prediction of gully formation in this study indicates concerns with the design and stability of the landform.

The model has clearly identified that the landform design needs to be revised. However, it also needs to be emphasised that several important caveats exist in the model assumptions and scenarios. These include the assumption that the landform was uniformly composed of the same waste rock material, that different surface treatments (e.g., rock-armoured drainage collection channels, erosion control structures and sediment traps) did not exist, and that no maintenance was performed on the landform in the period after rehabilitation. It is recognised that the final rehabilitated landform will be composed of a variety of different surface cover types and not a single surface type, as modelled here. This issue will be addressed in future modelling runs when the types and areas of cover of different surface types will be implicitly defined in a refined version of the landform design. Similarly, the 'worst case' scenario of an unvegetated landform persisting for 1,000 years is unrealistic for the Ranger site. However, it has been retained to provide an example of an extreme outcome.

This study focussed purely on the current mine operational area. Noting the need to include other surface cover characteristics, future assessments could extend the simulation area to include neighbouring natural features such as Georgetown Billabong, to determine the extent of delivery of eroded sediment from the rehabilitated landform into them. In particular, the delivery of suspended sediment should be implicitly estimated through the initial years, as it will be this fraction that will likely have the most potential for impact on the integrity of these water bodies. However, it should also be recognised that model results to date indicate that suspended sediment represents a very small proportion of the predicted total load, with the majority of the load composed of bedload.

Vegetation has a major effect on the erosion potential of the landform surface. The vegetation parameter values used in the model needs to be better defined to better account for the effects of developing vegetation cover over the area of the Ranger mine site. Given its role in the north Australian landscape, the role of fire, which may disrupt or prevent the development of specific vegetation communities, will also need to be considered.

Currently, the existing 22-year rainfall record from the Jabiru airport is looped to generate long-term rainfall sequences. This only represents the variability of rainfall events that have occurred over a relatively short period and runs the risk of not accounting for the full range of rainfall variability that might be expected over 1,000 years. An alternative approach would be to use 'weather generators' that create rainfall records based on statistical representations of measured rainfall in the region. This synthetic rainfall sequence is stochastic or random, so no two simulations will be identical. This means that many (100+) repeat simulations may be necessary, with mean outcomes used. Importantly, such a probabilistic approach also allows uncertainty in predictions to be better accounted for and provides a range or probability of likely outcomes. This is the only method at which millennial-scale quantitative assessments can be made within a risk framework.

The results of the simulations to date provide a guide for future enhancements both to the landform design and to the landform software model and provide increased confidence that the CAESAR-Lisflood model will be able to correctly predict the evolution of a rehabilitated landform once it has been constructed. 


\section{Acknowledgements}

The authors wish to thank David Jones, Wayne Erskine and Mike Saynor from the Supervising Scientist Division and Reid Miller, Peter Poole, Philippe Puig and Will Roney, formerly of Energy Resources of Australia, for their assistance in accessing and providing advice on data used in the landform assessment.

\section{References}

ATC Williams (2009) Pit Number 1 Consolidation and Backfill Feasibility Study ERA Ranger Mine, Northern Territory, Report for Energy Resources of Australia Pty Ltd, Document Number 107003R02.

Bates, P.D., Horritt, M.S. and Fewtrell, T.J. (2010) A simple initial formulation of the shallow water equation for efficient twodimensional flood inundation modelling, Journal of Hydrology, Vol. 387, pp. 33-45.

Coulthard, T.J., Kirkby, M.J. and Macklin, M.G. (2000) Modelling geomorphic response to environmental change in an upland catchment, Hydrological Processes, Vol. 14, pp. 2031-2045.

Coulthard, T.J., Macklin, M.G. and Kirkby, M.J. (2002) Simulating upland river catchment and alluvial fan evolution, Earth Surface Processes and Landforms, Vol. 27, pp. 269-288.

Coulthard, T.J., Lewin J. and Macklin, M.G. (2005) Modelling differential and complex catchment response to environmental change, Geomorphology, Vol. 69, pp. 224-241.

Cull, R., Hancock, G., Johnston, A., Martin, P., Marten, R., Murray, A.S., Pfitzner, J., Warner, R.F. and Wasson, R.J. (1992) Past, present and future sedimentation on the Magela plain and its catchment, in Modern Sedimentation and Late Quaternary Evolution of the Magela Plain, R.J. Wasson (ed), Supervising Scientist for the Alligator Rivers Region Research Report 6, AGPS, Canberra, pp. 226-268.

Einstein, H.A. (1950) The Bedload Function for Sediment Transport in Open Channel Flow, Soil Conservation Technical Bulletin No. 1026, U.S. Department of Agriculture, Washington, DC.

Erskine, W.D. and Saynor, M.J. (2000) Assessment of the off-site geomorphic impacts of uranium mining on Magela Creek, Northern Territory, Australia, Supervising Scientist Report 156, Supervising Scientist, Darwin.

Evans, K.G. (2000) Methods for assessing mine site rehabilitation design for erosion impact, Australian Journal of Soil Research, Vol. 38(2), pp. 231-248.

Hancock, G.R., Lowry, J.B.C., Coulthard, T.J., Evans, K.G. and Moliere, D.R. (2010) A catchment scale evaluation of the SIBERIA and CAESAR landscape evolution models, Earth Surface Processes and Landforms, Vol. 35, pp. 863-875.

Jones, D.R., Humphrey, C., van Dam, R., Harford, A., Turner, K. and Bollhoefer, A. (2009) Integrated chemical, radiological and biological monitoring for an Australian uranium mine - a best practice case study, in Proceedings International Mine Water Conference, 19-23 October, Pretoria, South Africa, pp. 95-104.

Laflen, J.M., Elliot, W.J., Simanton, J.R., Holzhey, C.S. and Kohl, K.D. (1991) WEPP soil erodibility experiments for rangeland and cropland soils, Journal of Soil and Water Conservation, Vol. 46(1), pp. 39-44.

Loch, R.J., Connolly, R.D. and Littleboy, M. (2000) Using rainfall simulation to guide planning and management of rehabilitated areas: Part 2, Computer simulations using parameters from rainfall simulation, Land Degradation and Development, Vol. 11(3), pp. 241-255.

Lowry, J.B.C., Coulthard, T.J., Hancock, G.R. and Jones, D.R. (2011) Assessing soil erosion on a rehabilitated landform using the CAESAR landscape evolution model, in Proceedings Sixth International Conference on Mine Closure (Mine Closure 2011), A.B. Fourie, M. Tibbett and A. Beersing (eds), 19-21 September 2011, Lake Louise, Canada, Australian Centre for Geomechanics, Perth, Vol. 1, Vol. 2, pp. 613-621.

McQuade, C.V., Arthur, J.T. and Butterworth, I.J. (1996) Climate and hydrology, in Landscape and Vegetation of the Kakadu Region, Northern Australia. C.M. Finlayson and I. von Oertzen (eds), Kluwer Academic Publishers, Dordrecht, pp. 17-35.

Moliere, D.R., Evans, K.G., Willgoose, G.R. and Saynor, M.J. (2002) Temporal trends in erosion and hydrology for a post-mining landform at Ranger Mine, Northern Territory, Supervising Scientist Report 165, Supervising Scientist, Darwin.

Onstad, C.A. and Foster, G.R. (1975) Erosion modelling on a watershed, Transactions of the American Society of Agricultural Engineers, Vol. 26, pp. 1102-1104.

Renard, K.G., Laflen, J.M., Foster, G.R. and McCool, D.K. (1994) The revised universal soil loss equation, in Soil Erosion Research Methods, R. Lal (ed), Soil and Water Conservation Society, Ankeny, lowa, 2nd edition, pp. 105-124.

Saynor, M.J. and Houghton, R. (2011) Ranger trial landform: particle size of surface material samples in 2009 with additional observations in 2010, Internal Report 596, August, Supervising Scientist, Darwin.

Saynor, M.J., Lowry, J., Erskine, W.D., Coulthard, T., Hancock, G., Jones, D. and Lu, P. (2012) Assessing erosion and run-off performance of a trial rehabilitated mining landform, Life of Mine Conference, Brisbane Queensland 10-12 July 2012.

Supervising Scientist Division (1999) Environmental Requirements for the Ranger Uranium Mine, Department of Sustainability, Environment, Water, Populations and Communities, viewed 3 April 2013, http://www.environment.gov.au/ssd/about/legislation/pubs/ranger-ers.pdf.

Van De Wiel, M.J., Coulthard, T.J., Macklin, M.G. and Lewin, J. (2007) Embedding reach-scale fluvial dynamics within the CAESAR cellular automaton landscape evolution model, Geomorphology, Vol. 90 (3-4), pp. 283-301.

Wilcock, P.R. and Crowe, J.C. (2003) Surface-based transport model for mixed-size sediment, Journal of Hydraulic Engineering, Vol. 129, pp. 120-128. 
Willgoose, G.R., Bras, R.L. and Rodriguez-Iturbe, I. (1989) A physically based channel network and catchment evolution model, TR 322, Ralph M., Parsons Laboratory, Department of Civil Engineering, Massachusetts Institute of Technology, Boston, Mass., $464 \mathrm{p}$.

Wischmeier, W.H. and Smith, D.D. (1978) Predicting rainfall erosion losses - a guide to conservation planning, Agriculture Handbook No. 537.2, U.S. Department of Agriculture, Washington, DC, 85 p. 